\title{
Accelerating Community College Graduation Rates: A Benefit-Cost Analysis
}

\author{
Henry M. Levin ${ }^{\mathrm{a}}$ and Emma García (10) \\ aTeachers College, Columbia University, New York, New York, USA; ${ }^{\mathrm{b} E c o n o m i c}$ Policy Institute and \\ McCourt School of Public Policy, Georgetown University, Washington, DC, USA
}

\begin{abstract}
This article reports a benefit-cost evaluation of the Accelerated Study in Associate Programs (ASAP) of the City University of New York (CUNY). ASAP was designed to accelerate associate degree completion within 3 years of degree enrollment at CUNY's community colleges. The program evaluation revealed that the completion rate for the examined cohort increased from $24.1 \%$ to $54.9 \%$, and cost per graduate declined considerably (Levin \& Garcia, 2012; Linderman \& Kolenovic, 2012). The returns on investment to the taxpayer include the benefits from higher tax revenues and lower costs of spending on public health, criminal justice, and public assistance. For each dollar of investment in ASAP by taxpayers, the return was $\$ 3$ to \$4. For each additional graduate, the taxpayer gained an amount equal to a certificate of deposit with a value of $\$ 146,000$ (net of the costs of the investment). Based on these estimated returns, a cohort of 1,000 students enrolled in ASAP would generate net fiscal benefits for the taxpayer of more than $\$ 46$ million relative to enrolling in the conventional degree program. ASAP results demonstrate that an effective educational policy can generate returns to the taxpayer that vastly exceed the public investment required.
\end{abstract}

\section{ARTICLE HISTORY}

Received 13 June 2016

Accepted 27 March 2017

\section{KEYWORDS}

Community college; costbenefit analysis; degree completion; evaluation framework; higher education interventions; policymaking; public investment

\section{Introduction}

In 2009, more than 7.5 million students attended community colleges in the United States (Bureau of the Census, U.S. Department of Commerce, 2012). Although these institutions provide opportunities for entry into higher education because of their geographic accessibility, adaptability to student and employer educational needs, transfer routes to 4-year institutions, and flexibility in scheduling and composition of courses, the reality is that relatively few students complete their studies. According to the U.S. Department of Education, only about $22 \%$ of students who enroll in community colleges complete an associate degree 3 years later (Snider \& Dillow, 2011), and completion rates are even lower in urban institutions. ${ }^{1}$ 
This challenge was recognized by the City University of New York (CUNY) in launching a comprehensive program to assist students in completing their associate degrees, with financial support from the New York City Center for Economic Opportunity. The program, Accelerated Study in Associate Programs (ASAP), was designed to increase dramatically the number of students who complete an associate degree in a timely manner (Linderman \& Kolenovic, 2012). The goal of ASAP was to graduate at least "[...] $50 \%$ of students within 3 years through provision of comprehensive support services and financial resources that remove barriers to full-time study, build student resiliency, and support degree completion" (Linderman \& Kolenovic, 2012, p. 9). ${ }^{2}$

ASAP was initially established at CUNY's six community colleges ${ }^{3}$ and uses a comprehensive design to overcome the obstacles to timely degree completion (for full-time students with no developmental needs). To counter these obstacles, the program enlists a variety of interconnected supports (Linderman \& Kolenovic, 2012, pp. 10-11). The comprehensive services provided to the students include financial incentives, a consolidated schedule, regular advisement, cohort groups with faculty support, career preparation, and extra academic assistance (Linderman \& Kolenovic, 2012, pp. 10-12).

Careful assessment of ASAP by the CUNY research team provided early evidence of its promise, with about half (54.9\%) of its initial cohort of 1,132 students who started community college in the fall of 2007 having earned an associate degree 3 years later in comparison with only about a quarter of a matched comparison group of students (24.1\%) who did not benefit from inclusion in ASAP (Linderman \& Kolenovic, 2012). ${ }^{4}$ This evaluation was accomplished by propensity score matching of ASAP students with a statistically similar group in terms of demographic characteristics, academic major, and educational preparedness, and it was based on optimal matching technology (Linderman \& Kolenovic, 2012). The technical results of the evaluation showed that the process reduced bias, and outcome analyses based on the matched sample were "free of overt selection bias." 5 , For the initial cohort, a cost-effectiveness study showed that ASAP was a cost-effective intervention, saving about $\$ 6,500$ per completed degree compared with the cost per graduate in the conventional program without ASAP (Levin \& Garcia, 2012). It should be noted that several other evaluations of the program's success have been done for subsequent student groups and have generally shown trials that ASAP doubles the number of graduates. For example, MDRC undertook a randomized controlled evaluation of ASAP in 3 colleges including students with developmental needs and found a doubling of associate degree completions in 3 years as well as higher transfer rates and accumulation of more credits (Scrivener et al., 2015). 


\section{Return on investment: A benefit-cost analysis}

On the basis of the program's promise and relative effectiveness documented earlier and recognized by The White House's Improving College Opportunity Initiative (The White House, 2014a, 2014b), CUNY considered the expansion of the program in terms of number of participants, programs served, and sites. To guide this decision, it was necessary to ascertain whether ASAP was a good investment for the taxpayer by examining whether the benefits of investing in ASAP exceeded the costs. ${ }^{7}$ The benefit-cost analysis undertaken in this article focused on this goal. In doing so, we estimated both costs and benefits associated with ASAP with a special focus on the returns of the investment to the taxpayers, because the cost is mainly funded from public sources.

Benefit-cost analyses enable us to ascertain whether a particular intervention is "worth it" by comparing the costs in monetary terms with the value of the benefits in monetary terms. In the case of improving graduation prospects, there are obvious benefits to the student in terms of better employment and job opportunities and improved options for further education, as well as better health, greater knowledge, and the ability to learn new things. But there are also benefits to the taxpayers who pay much of the cost of public investment in community colleges. Increasing the numbers and quality of educated persons in society benefits society in the form of higher economic productivity and income, as well as greater technological advancement and inventive activity. Society also experiences fiscal benefits in higher tax revenues and reduced costs for spending on public health, criminal justice, and public assistance (Belfield \& Levin, 2007b).

Using this framework, this study compared the benefits and costs of additional associate degrees produced by ASAP (i.e., the program's objective) to ascertain if the benefits exceed the costs and the magnitude of the differences. ${ }^{8}$ The calculation was made for both the taxpayer and the individual ASAP student, using a conservative approach in both cases (see "Methods" section).

The basic method for making such benefit-cost calculations has been used in education since the early 1960s, when economists refined the method of analysis for investment in human capital (Becker, 1964). Economists found that investments in education showed rates of return that were comparable to or greater than those found for investments in physical capital-that is, productive facilities and equipment, the traditional focus of investment. Although this literature referred largely to the "profitability" of individuals investing in further education through gains in income, it extended to the value of social benefits of investing in education.

The first attempt to apply these methods to a benefit-cost analysis of taxpayer investment was conducted in 1972 with an analysis of the costs and benefits of reducing high school dropouts (Levin, 1972). This study 
compared the costs of reducing dropouts to the benefits of increased income and tax revenues as well as reduced costs of public assistance, crime, and public health. The limited informational resources and statistical methods available 40 years ago restricted the comprehensiveness and precision of benefit-cost estimates, but even with conservative assumptions, it appeared that the benefits to the taxpayer of reducing high school dropouts exceeded the costs by at least 2 to 1 .

A more refined analysis was applied to an experimental study of a specific investment in early childhood education in the famous Perry Preschool evaluation. Children aged 3 years and 4 years from poor families were randomly assigned to an experimental group that received a quality preschool program or a control group that did not. When the same children were aged 19 years, it was found that the preschool recipients had greater educational success, lower crime rates, and greater employment prospects than the comparison group who had not been enrolled in the preschool. A calculation of benefits to the taxpayer showed that for every dollar of investment cost, the benefits exceeded \$6 (Barnett, 1985). The follow-up studies of the two groups at ages 27 and 40 years confirmed even greater benefits (Belfield, Nores, Barnett, \& Schweinhart, 2005).

Dramatic improvements in data sources and social science modeling of benefits have generated studies of benefits and costs of specific educational programs to reduce the number of high school dropouts (Belfield \& Levin, 2007a). Five studies were selected from experimental and quasiexperimental evaluations that showed evidence of increasing graduation rates. The public costs of these programs were compared to the public benefits in terms of higher tax revenues and reductions in public costs of crime, health, and public assistance. All five programs showed benefits in excess of costs, with the median program among the five showing that fiscal benefits would exceed costs by $\$ 127,000$ for each additional graduate over a lifetime when valued at age 20 years (Levin \& Belfield, 2007a; Levin, Belfield, Muennig, \& Rouse, 2007). Independent studies were also carried out for individual states with similar results (e.g., Belfield \& Levin, 2007a).

\section{Methods}

The general approach used for measuring the benefits of education consisted of first identifying the impact and associated benefit categories and the evidence behind them and then placing values on benefits (Levin \& McEwan, 2001). In the case of completion of an associate degree, the benefits are associated with greater adult success of the individual relative to what the individual would have experienced if he or she had terminated education at the end of high school. Substantive empirical evidence has shown that individuals with more education obtain higher earnings and pay greater 
taxes (Rouse, 2007), experience better health and lower likelihood of drawing on government health services (Muennig, 2007), are less likely to engage in crime and to enter the criminal justice system (Moretti, 2007), and are less likely to require public assistance (Waldfogel, Garfinkel, \& Kelly, 2007). All of these better outcomes provide benefits to society and the taxpayer by increasing public revenues and reducing the costs of public services. It is this increase in public income and reduction in public costs that constitute many of the public benefits of additional educational attainment.

We followed this general approach for the evaluation of ASAP. In the case of ASAP, the increased number of graduates among ASAP participants versus the traditional program or comparison group was the metric used to evaluate the program's effect (see evaluations by CUNY and MDRC). For each additional degree (both under ASAP or in the treatment group and following the traditional program or comparison group), the benefits and costs were estimated by comparing the net benefits of graduating versus not graduating (i.e., receipt of only a high school diploma). The results of our analysis are thus expressed in per-graduate terms, or as costs and benefits per additional graduate in the ASAP program relative to the comparison group (see Levin et al., 2007, among others, for a similar approach). ${ }^{9}$

We expected that the additional associate degrees would produce benefits for the ASAP students as well as for the taxpayer. That is, more associate degrees translate into greater employment and higher income and tax revenues as well as lower costs for public health, crime, and public assistance. As much as possible, we used estimates of effects based on causal models from the academic literature rather than accepting mere correlation when modeling the relationships between the educational outcomes and the benefits. Also, because CUNY is funded by both New York state and New York City, we attempted to use measures of benefits to the taxpayers for these two entities when available. Other methodological aspects and assumptions are explained in the next paragraphs.

\section{Present value}

Both benefits and costs were based on comparing benefits and costs of 3-year associate degree recipients to those of high school completers who had not entered postsecondary education. ${ }^{10}$ Costs and benefits are stated in terms of present values (PV) in 2010, which is the 3-year graduation mark for students in the initial ASAP cohort and the cohort that served as the basis of our study. PV enables comparison of costs and benefits that are accrued over different periods of time. For the costs of a typical ASAP graduate-23 years old $^{11}$-costs are accumulated from age 20 years to 23 years. Subsequently, the benefits of the additional education are estimated for ages 23 years to 65 years. Following the standards in the literature, we used 
a discount rate equal to $3.5 \%$ (Moore et al., 2004). ${ }^{12}$ The results of the analysis are expressed in net PV or net benefits produced by the investment, measured in 2010 dollars, as well as in benefit-to-cost ratios for taxpayers and students.

\section{Data}

Unlike other benefit-cost studies that have used national data, the current evaluation relied on New York City or New York state data as much as possible to reflect the sources of public funding of CUNY. Because, to a very high degree, CUNY's community college graduates remain in the New York metropolitan area and in New York City (see later section on mobility), data collection at the city level was prioritized. ${ }^{13}$

\section{Conservative estimates}

Our approach understates ASAP's net benefits to the taxpayer by inducing a conservative bias to the results (as recommended by Levin \& McEwan, 2001). ${ }^{14}$ For example, if ASAP induced more students to increase their education, even though falling short of graduation, omitting the benefits of individuals with partial completion (or some college) underestimates the benefits of ASAP. Similarly, the analysis was limited to estimating the benefits of higher associate degrees within three years, disregarding additional benefits (and costs) associated with higher educational attainment from students who transfer to 4-year institutions or from associate degrees produced after the three year window.

Assumptions on the labor market trajectories were also conservative. First, we projected that the earnings profile of current graduates would follow the earnings profile at all ages of the 2008 to 2010 holders of an associate degree (adjusted by a moderate increase in productivity). The labor market situation in that period was characterized by relatively poor conditions, but the recovery period since that time has shown grounds for greater optimism. Second, although an obvious concern is the general equilibrium effect of more graduates in the labor market, which could eventually reduce the returns to each additional graduate if the supply of graduates in the market increased and the demand for associate degrees held constant, evidence suggests otherwise. In actuality, the overall trend in U.S. labor markets has witnessed a rise in the relative economic value of postsecondary education in comparison with that of high school graduates. Empirical studies have confirmed that even with massive increases in community college graduates, changes in technology and work organization and the decline of manufacturing have increased the demand for postsecondary educational skills relative to lower levels of education, without declines in economic returns (Marcotte, 
Bailey, Borkoski, \& Kienzl, 2005). Conservatively, our estimates assumed that productivity increases would be equal for the two skill groups.

Lastly, there are many benefits of higher education that are identified in the literature, but they lack accurate measurement or monetary values. McMahon (2009) has provided one of the most comprehensive presentations and discussions of these benefits. ${ }^{15}$ The incomplete assessment of these benefits also imparts a conservative estimate of the payoffs to the investment in ASAP.

\section{Costs per associate degree}

Levin and Garcia (2012) estimated the costs of producing additional associate degrees within a 3-year period for both the regular programs of CUNY and with the added support required for ASAP. The basic method of establishing costs was to first calculate for the ASAP group the costs of their aggregate, full-time equivalent (FTE) enrollments over 3 years. ${ }^{16}$ This number was compared to the overall costs of FTE students of the comparison group who had not received ASAP services. The costing method of the two programs was based partially on an ingredients-based approach (Levin \& McEwan, 2001) and on budgetary information provided by ASAP-CUNY. These costs were then divided by the respective numbers of associate degrees produced in each group during the 3-year period to determine a cost per graduate. Even with the additional spending for ASAP services, the cost per graduate-the program's cost-effectiveness metric-was less than it was for the comparison group because of the much higher yield of graduates (about $55 \%$ for ASAP and 24\% for the comparison group).

Table 1 shows the total institutional cost per graduate. The overall institutional cost incurred by CUNY for each associate degree (expressed in PV at age 23 years in 2010 dollars) was about \$59,000 for the ASAP students and almost $\$ 66,000$ for the comparison group. Although the cost per ASAP student was higher than for the traditional student because of the extra services, the institutional cost for each graduate was less for students in ASAP because of the considerably higher graduation rates for ASAP. ${ }^{17}$

Table 1. Total institutional cost per graduate and total cost for the student.

\begin{tabular}{lccc}
\hline & Total Comparison & Total ASAP \\
\cline { 2 - 2 } & Fall 2006 Comparison Group & & Fall 2007 ASAP Group \\
\hline Total Institutional Cost Per Graduate $^{\mathrm{a}}$ & $\$ 65,900$ & $\$ 59,300$ \\
Total Cost for the Student $^{\mathrm{b}}$ & $\$ 21,000$ & $\$ 13,100$ \\
\hline
\end{tabular}

Note. ASAP = Accelerated Study in Associate Programs. (a) The total institutional cost per graduate is the capitalized average cost per graduate at age 23 years in 2010 dollars (see Levin \& Garcia, 2012, Table 5). (b) The total cost for the student includes the institutional cost per graduate for the student, the net forgone earnings, and textbooks and transportation (see Levin \& Garcia, 2013, Table 16). Monetary values have been rounded to the closest hundred-dollar value (because of rounding, totals may differ slightly from sum of numbers). 
Students incur costs because they may forgo earnings during the period of study and must pay for materials and other costs related to their education. Costs to the student include three components: student tuition, educational materials, and transportation-plus the loss of earnings (or opportunity cost). Total costs to the student were $\$ 21,000$ for the comparison group and about $\$ 13,000$ for the ASAP group (see Table 1). Students in ASAP are subsidized for fees or tuition after application of need-based financial aid awards (i.e., federal Pell and New York State Tuition Assistance Plan) as well as transportation and textbooks, but they typically must forgo some earnings while they are studying. Students in the conventional group must incur all of these costs. We used the information on average tuition as reported on CUNY's Web site ${ }^{18}$ and on financial aid based on CUNY ASAP's analysis of student financial aid data from the CUNY Institutional Research Database. Net tuition is the difference between total tuition and financial aid award for students in the comparison group. For students in ASAP, the gap between tuition and fees and a financial aid award is waived. We used data from the American Community Survey (ACS) and selected the subsample of observations in the city of New York to compute forgone earnings. ${ }^{19}$ Finally, we added the estimated costs of the textbooks and transportation per student in the comparison group by basing it on the regular costs in this category for CUNY students. ${ }^{20}$ For ASAP students, the costs of textbooks and transportation were covered by the program.

\section{Benefits of ASAP}

Although the costs differ between the two programs for producing an associate degree, the average benefits for a CUNY associate degree are assumed to be similar for the two groups because they have similar graduation requirements. Consequently, we assumed that both ASAP and non-ASAP graduates generated the same benefits per degree. The major difference educationally is that a far higher proportion of the non-ASAP students reduce their participation sharply or drop out, resulting in their lower associate degree completion rates. The higher yield of ASAP in completion rates means that the aggregate benefits for any initial group of ASAP enrollees will exceed considerably the aggregate benefits for a similar number of enrollees who are not recipients of ASAP services.

Specific benefits of increased associate degree attainment include:

- additional income reflecting higher productivity and trainability of an associate degree completer relative to a high school graduate, reflecting benefits to the student and to society;

- higher tax revenues derived from the additional income, reflecting fiscal benefits to the taxpayer;

- reduced costs of public services for crime, public health, and public assistance, reflecting fiscal benefits to the taxpayer; and 
- overall gains in productivity of other workers created by the presence of a more educated workforce.

We first estimated the return on investment to the taxpayer in terms of higher taxes generated by the increase in associate degrees and the reduction in cost of public services associated with the additional education. These are the fiscal returns to taxpayer investment in ASAP. In later sections, we will consider other benefits to both individuals and society.

\section{Education, income, and tax revenues}

One of the most powerful and consistent findings in the economics of education is the measurable impact of additional education in producing additional economic opportunity for both the individual worker and society. Workers with more education are valued more highly in the workplace because they tend to be more proficient at jobs, benefit more from additional training, and make better and more productive decisions in the allocation of resources, including the use of their own time. Out of their higher income, they pay greater taxes, which reduce the burden on other taxpayers.

We compared the income and tax contributions of individuals with an associate degree who graduated within 3 years from ASAP to those who obtained high school completion or its equivalent. ${ }^{21} \mathrm{We}$ calculated the benefits for the individuals and the taxpayer along the following dimensions: earnings, income tax contributions, property taxes, sales taxes, and local income taxes.

\section{Income gains}

The relationship between education and earnings has been largely documented in the empirical research (Angrist \& Krueger, 1991,1999; Ashenfelter \& Rouse, 1998; Card, 1999; Griliches, 1979), as has the evidence for causality rather than just correlation (Card, 1999; Rouse, 2007). On average, individuals with higher educational levels have higher earnings. ${ }^{22}$ They are also more likely to be employed. ${ }^{23}$

To calculate the average earnings differentials between individuals with high school completion versus an associate degree in New York City, we exploited the ACS between 2008 and 2010. We used population-weighted means for the inflation-adjusted wages and salaries of individuals in New York City, aged 23 to 65 years old, and assumed that productivity grows at a constant rate of $1.5 \%$ per year (see Rouse, 2007, p. 114). The values are expressed in constant dollars by adjusting all values to the 2010 price level.

To assess the private income benefits for the student, we compared the PV of income from age 23 years to age 65 years for those with associate degrees and those with a high school diploma, as shown in Table 2. The total or 
Table 2. Lifetime earnings by educational attainment (present value at age 23 years at $3.5 \%$ discount rate), 2008-2010.

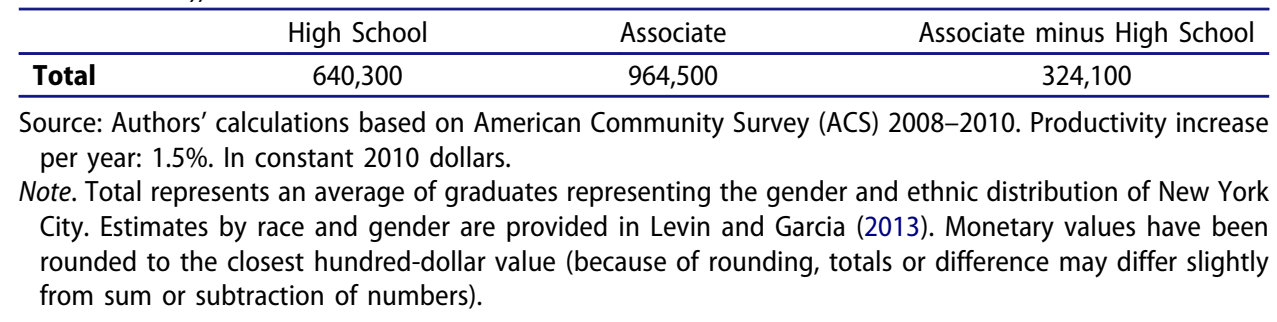

average for the overall group is an average based on the overall composition of the New York City population. We assigned this outcome to CUNY graduates on the premise that CUNY community college enrollments are demographically representative of the population in New York City. ${ }^{24}$ The advantage in PV of lifetime earnings for associate degree recipients is, on average, about $\$ 324,000$. This is a substantial lifetime premium for an associate degree. Because degree requirements are similar for both ASAP and non-ASAP graduates, we assumed that the income benefits would be similar too.

\section{Additional tax revenues from state and federal income tax}

The higher income for individuals with an associate degree is an important source of additional fiscal gains for taxpayers (Rouse, 2007). ${ }^{25}$ To estimate the expected state and federal taxes for Social Security and Medicare (Federal Insurance Contributions Act, or FICA) taxes paid by individuals with earnings, we used the National Bureau of Economic Research (NBER)-Taxsim, Version 9.0, which was designed for this purpose. ${ }^{26}$ To provide information that is representative of the potential benefits of the CUNY ASAP graduates, who are likely to remain in the New York metropolitan area (or elsewhere in New York state), we used income tax estimates based on residents of New York state ${ }^{27}$ who were single (following Rouse, 2007, pp. 108-109), ${ }^{28}$ had income only from earnings, and had no itemized deductions. We used the fiscal structure existing in 2010 and the consumer price index adjusted to constant 2010 dollars. The tax base was adjusted for a yearly $1.5 \%$ productivity increase.

Table 3 summarizes the estimates of taxes paid by high school completers and associate degree recipients, on average (expressed in PVs at age 23 years and in 2010 constant dollars). The first three columns show the amount of federal, state, and FICA taxes paid by individuals. On average, individuals with an associate degree are expected to contribute $\$ 106,000$ in federal taxes, $\$ 45,000$ in state taxes, and about $\$ 148,000$ in FICA taxes over their lifetime. In contrast, individuals who completed high school would pay about $\$ 46,000$ in federal taxes, $\$ 24,000$ in state taxes, and almost $\$ 98,000$ in FICA tax contributions over their lifetime. 
Table 3. Lifetime taxes from earnings, city, property, and sales taxes by educational attainment (present value at age 23 years at $3.5 \%$ discount rate).

\begin{tabular}{lccc}
\hline & $\begin{array}{c}\text { High School } \\
\text { Completers }\end{array}$ & $\begin{array}{c}\text { Associate Degree } \\
\text { Recipients }\end{array}$ & $\begin{array}{c}\text { Associate Minus High } \\
\text { School }\end{array}$ \\
\hline $\begin{array}{l}\text { Total tax } \\
\text { By type of tax: }\end{array}$ & $\mathbf{2 3 3 , 3 0 0}$ & $\mathbf{3 9 8 , 7 0 0}$ & $\mathbf{1 6 5 , 4 0 0}$ \\
$\begin{array}{l}\text { Federal Income Tax Liability After } \\
\quad \text { All Credits }\end{array}$ & 45,700 & 106,300 & 60,600 \\
$\begin{array}{l}\text { State Income Tax Liability After All } \\
\quad \text { Credits }\end{array}$ & 23,600 & 45,500 & 21,900 \\
FICA (OADSI \& HI, Employee \& & 98,000 & 147,600 & 49,600 \\
$\quad$ Employer) & 26,800 & 40,300 & 13,500 \\
City Income Tax (Net) & 7,500 & 11,300 & 3,800 \\
Property Tax & 16,000 & 24,100 & 8,100 \\
NYC Sales Tax & 15,700 & 23,600 & 7,900 \\
NY State Sales Tax & & & \\
\hline
\end{tabular}

Source: Earnings' taxes calculated based on American Community Survey (ACS) 2008-2010 and National Bureau of Economic Research (NBER)-Taxsim, Version 9.0, in constant 2010 dollars.

Note. FICA = Federal Insurance Contributions Act; OADSI = Old-Age, Survivors, and Disability Insurance; $\mathrm{HI}=$ Hospital Insurance. Productivity increase of income (the tax base) is $1.5 \%$ per year. City income, property, NYC sales, and NY state taxes are calculated based on ACS 2005-2010 and city and state sources (see Levin \& Garcia, 2013 , Table A1). Monetary values have been rounded to the closest hundred-dollar value. Totals may not sum to total due to rounding.

\section{Additional tax revenues from city income, property, and sales taxes}

We calculated the sales, property, and other local taxes for individuals who resided in New York City (using the information listed in Levin \& Garcia, 2013, Appendix Table A1). Results are shown in Table 3 (see bottom rows). On average, an associate degree recipient pays almost $\$ 100,000$ in these taxes over a lifetime in $\mathrm{PV}$ at age 23 years $(\$ 40,300$ in city income tax, $\$ 11,300$ in property tax, and about $\$ 40,000$ in sales taxes), compared with almost $\$ 66,000$ paid by the average person who graduated from high school (the breakdown for this person is $\$ 26,800$ in city income tax, $\$ 7,500$ in property tax, and about $\$ 32,000$ in sales taxes).

\section{Overall tax burden}

Individuals with an associate degree contribute, on average, almost $\$ 398,700$ in lifetime taxes (overall tax contributions from earnings, property, and sales) in PV at age 23 years (Table 3). Individuals with a high school diploma or GED pay, on average, about $\$ 233,300$ in total tax contributions over their lifetime. On average, a person with an associate degree contributes $\$ 165,400$ more in tax revenues than a person who completed high school. The additional tax revenues, alone, from an associate degree are about twice as large as the public investment required to fund the degree.

\section{Reduced costs of public services to taxpayer}

Benefits of additional education to taxpayers also include reductions in the taxpayer cost of public services. As indicated earlier, greater educational 
attainment will place fewer cost burdens on public services for health, public assistance, and criminal justice.

\section{Health}

Considerable empirical literature has summarized the relationship between education and health (e.g., Cutler \& Lleras-Muney, 2010; Lleras-Muney, 2005). Almost all measures of health status are positively related to educational attainment. Education may improve health through such mechanisms as healthier lifestyles in terms of nutrition, exercise, and reductions in substance abuse; better health decisions because of better knowledge and more scientific ways of addressing health needs; and the obvious possibility that more education may be associated with other social advantages that correlate with better health. In their exercise to estimate the causal relationship between education and health, Cutler and Lleras-Muney (2010) found that a substantial portion of the education advantage is due to knowledge and cognitive ability. To estimate the public cost savings on health from receipt of associate degrees, we used the Medical Expenditures Panel Survey 2008 (MEPS), which includes information on public medical expenditures by education level. $^{29}$

Table 4 shows the PV at age 23 years of total health expenditures by educational attainment (expressed in 2010 constant dollars). The table shows the breakdown by source of payment. Total public health expenditures for individuals with an associate degree were, on average, about $\$ 15,000$ in PV at age 23 years. Total public health expenditures for individuals who completed high school (or with 12 years of education) were about $\$ 20,000$, about one third higher than for those with an associate degree. Coverage of Medicare for those younger than 65 years was limited to chronic disease and was not restricted by income. It was similar for both groups, although associate degree recipients may be better informed about this coverage. On average,

Table 4. Lifetime public health expenditures, by educational attainment (present value at age 23 years at $3.5 \%$ discount rate).

\begin{tabular}{lcc}
\hline & 12 Years of Education (High School) & 2 Years of College (Associate Degree) \\
\hline Total Public Expenditures & 20,100 & 15,100 \\
By source of payment: & 6,900 & 6,400 \\
Medicare & 10,200 & 5,300 \\
Medicaid & 1,300 & 1,300 \\
Veterans' Affairs (VA) & 500 & 700 \\
TRICARE & 100 & 0 \\
Other Federal Sources & 700 & 500 \\
Other State and Local Sources & 500 & 800 \\
Other Public & & \\
\hline
\end{tabular}

Source: Author's calculations using Medical Expenditures Panel Survey (MEPS)-2008; weighted means, individuals living in an metropolitan statistical area (MSA) (all regions), ages 23 to 65 years, in 2010 constant dollars.

Note. Monetary values have been rounded to the closest hundred-dollar value. Totals may not sum to total due to rounding. 
Table 5. Lifetime public assistance costs, by educational attainment (present value at age 23 years at $3.5 \%$ discount rate).

\begin{tabular}{lcc}
\hline & High School & Associate Degree \\
\hline Total Public Assistance & $\mathbf{\$ 1 7 , 1 0 0}$ & $\mathbf{\$ 1 , 1 0 0}$ \\
By type: & & \\
Welfare Income $^{\mathrm{a}}$ & $\$ 2,200$ & $\$ 1,400$ \\
Supplemental Security Income $^{\mathrm{a}}$ & $\$ 4,700$ & $\$ 3,000$ \\
Housing Subsidy $^{\mathrm{b}}$ & $\$ 200$ & $\$ 100$ \\
Food Stamps $^{\mathrm{b}}$ & $\$ 6,000$ & $\$ 2,800$ \\
Unemployment Compensation $^{\mathrm{b}}$ & $\$ 3,900$ & $\$ 3,700$ \\
\hline
\end{tabular}

Note. Source: (a) American Community Survey (ACS) 2005-2010, weighted means, individuals 23 to 65 years in New York City. This variable shows how much pretax income the respondent received during the previous year from various public assistance programs commonly referred to as "welfare." (b) Trostel (2010), in 2010 constant dollars. Monetary values have been rounded to the closest hundred-dollar value. Totals may not sum to total due to rounding.

a person with an associate degree costs $\$ 5,000$ less in public health expenses than does a person who completed high school, with most of the difference found in Medicaid coverage.

\section{Public assistance}

In 1996, the federal government passed welfare or public assistance reform, reducing dramatically the numbers who were eligible for traditional welfare payments and requiring work assignment and training as well as limiting the length of time that payments could be received. The following years also witnessed economic growth that further reduced welfare dependency. As a result, the overall participation in and cost of welfare declined considerably for both New York City (Chernick \& Reimers, 2004) and the rest of the nation.

Table 5 shows the present discounted value at age 23 years of the lifetime stream of income received through welfare assistance (expressed in constant dollars for 2010). ${ }^{30}$ Total public assistance and welfare income was, on average, about $\$ 11,000$ for individuals with an associate degree compared with about $\$ 17,000$ in PV for lifetime receipt of public assistance for high school graduates. Readers should keep in mind that the average payment per member of any education group will be very low if few members of that group receive benefits. That is, these figures are not for each welfare recipient but are averages determined by dividing payments over all members of the educational group, whether receiving public assistance or not.

\section{Crime}

The relation between education and crime has been studied extensively and has been summarized by Lochner (2011). Higher incomes of the more educated raise the risk or opportunity cost of committing a crime. Education also induces individuals to reduce impulsive behavior (as suggested by Becker \& Mulligan, 1997) and the tendency to take risks. By 
increasing the expected future punishment in terms of income forgone, education discourages crime. Lochner and Moretti (2004) used a causal modeling approach to estimate the impact of education on commission of different crimes, using the U.S. population census and crime reports from the Federal Bureau of Investigation.

Following Belfield, Levin, and Rosen (2012), we took into account public costs associated with correction, police protection, and other costs of the criminal justice system to estimate the total burden associated with crime. We used information from Trostel (2010), who calculated national estimates of lifetime corrections costs (which include probation; see footnote 24 of his study) for individuals with high school credentials and associate degrees, and from Belfield et al. (2012) for the other crime-related categories (police protection costs and judicial and legal costs; see Appendix Table 2, p. 39 in their study). Total expected public savings from lower criminal involvement of associate degree recipients relative to high school graduates (Table 6) was about $\$ 29,000$ per additional associate degree.

\section{Summary of taxpayer benefits}

Table 7 provides a summary of the direct fiscal benefits to the taxpayer for producing an additional associate degree. Most of the benefits are generated from the additional tax revenues of associate degree recipients, amounting to about $\$ 165,000$ (or $80 \%$ ). However, there are substantial benefits from reduced costs of public health, public assistance, and criminal justice, amounting to about $\$ 40,000$ (or 20\%). Overall, each additional associate degree provides fiscal benefits to the taxpayer of $\$ 205,500$ in PV of lifetime benefits at age 23 years. That is, the achievement of an associate degree by high school completers provides considerable relief for the taxpayer.

Table 6. Lifetime public crime costs, by educational attainment (present value at age 23 years at $3.5 \%$ discount rate).

\begin{tabular}{lcc}
\hline & High School & Associate Degree \\
\hline Total Public Crime & $\mathbf{\$ 1 1 , 9 0 0}$ & $\mathbf{\$ 1 2 , 7 0 0}$ \\
By area: & & \\
Correction & $\$ 11,400$ & $\$ 3,500$ \\
Judicial and Legal & $\$ 14,900$ & $\$ 4,500$ \\
Police Protection $^{\mathrm{a}}$ & $\$ 15,600$ & $\$ 4,700$ \\
\hline
\end{tabular}

Source: Trostel (2010) and Belfield et al. (2012).

Note. (a) This value corresponds to half of the amount that would be estimated using Belfield et al.'s (2012) calculation. We assumed that half of the total amount spent on prevention activities is devoted to crime prevention and crime apprehension. In constant 2010 dollars. Monetary values have been rounded to the closest hundred-dollar value. Totals may not sum to total due to rounding. 
Table 7. Generation of total fiscal benefits to the taxpayer per degree (present value of lifetime benefits at age 23 years).

\begin{tabular}{lc}
\hline & Per Additional Associate Degree \\
\hline Total Public Benefits & $\mathbf{\$ 2 0 5 , 5 0 0}$ \\
By area category of benefits: & \\
Tax Revenues From Income & \\
Property and Sales Taxes & $\$ 145,600$ \\
Public Savings: & $\$ 19,800$ \\
Health Expenditures & \\
Welfare and Public Assistance $^{\mathrm{a}}$ & $\$ 5,000$ \\
Criminal Justice & $\$ 6,000$ \\
\hline
\end{tabular}

Note. (a) Includes federal, state, Federal Insurance Contributions Act, and city income taxes; (b) includes Medicare, Medicaid, VA, TRICARE, other federal, state, and local sources, and other public. In constant 2010 dollars.

\section{Net benefits of ASAP for the taxpayer}

Although there are considerable benefits to the taxpayer from this investment, it is important to take account of the investment cost to produce an associate degree. There are two ways to express this comparison. The first is to subtract the cost of the taxpayer investment for increasing the number of associate degree holders from the taxpayer benefits produced by the additional associate recipients. A second way is to provide the ratio of benefits to costs to ascertain the dollar return in benefits for each dollar of costs. Table 8 provides estimates for both types of comparisons.

Total institutional cost per graduate in Table 8 is taken from Table 1 and is about $\$ 66,000$ for the comparison group and about $\$ 59,000$ for ASAP. We have assumed for simplicity that the public institutional cost per graduate is charged to the taxpayer. As mentioned earlier, this is an overestimation of the public cost because some of this cost will be paid by the student. By overstating the public costs, we are understating the difference between benefits and costs because of the inclusion of the student fees in the taxpayer burden.

Table 8 also shows that the total fiscal benefits received by the taxpayer per additional degree are $\$ 205,500$ (from Table 7). The net benefits received by the taxpayer, however, require deduction of the investment required to

Table 8. Benefit-to-cost comparisons for the taxpayer: Total institutional costs versus direct benefits.

\begin{tabular}{ccccc}
\hline & $\begin{array}{c}\text { Benefits Per Additional } \\
\text { Degree (Taxpayer) }\end{array}$ & $\begin{array}{c}\text { Institutional Cost Per } \\
\text { Graduate (Taxpayer) }\end{array}$ & $\begin{array}{c}\text { Benefits Minus Costs } \\
\text { (Net Benefits) } \\
\text { (Taxpayer) }\end{array}$ & $\begin{array}{c}\text { Benefit- } \\
\text { Cost } \\
\text { Ratio } \\
\text { (Taxpayer) }\end{array}$ \\
\hline $\begin{array}{c}\text { Fall 2006 } \\
\quad \begin{array}{l}\text { Comparison } \\
\text { Group }\end{array}\end{array}$ & $\$ 205,500$ & $\$ 65,900$ & $\$ 139,600$ & 3.1 \\
$\begin{array}{c}\text { Fall 2007 ASAP } \\
\text { Cohort }\end{array}$ & $\$ 205,500$ & $\$ 59,300$ & $\$ 146,200$ & 3.5 \\
\hline
\end{tabular}

Note. ASAP = Accelerated Study in Associate Programs. In constant 2010 dollars. Monetary values have been rounded to the closest hundred-dollar value. Totals and ratios may not sum to total due to rounding. 
obtain the fiscal benefits. After accounting for the cost of the investment, there is a net return in the PV of benefits to the taxpayer of about $\$ 140,000$ for each additional graduate in the comparison group and about $\$ 146,000$ for each additional ASAP graduate. The benefit-to-cost ratio for the taxpayer is 3.1 for each additional graduate in the comparison group and 3.5 for each additional ASAP graduate. This means that each additional associate degree graduate provides $\$ 3$ to $\$ 4$ in return to the taxpayer for every dollar of taxpayer investment. Expressed in terms of a certificate-of-deposit (CD) type of investment returned to the taxpayer, each additional associate degree graduate from ASAP provides to the taxpayer the equivalent of a CD worth $\$ 146,000$, a very sizable amount.

Although this is a very impressive return on public investment for each graduate, it does not take into account the massive increase in numbers of additional graduates attributed to ASAP, or the total benefits of the program (serving the analyzed cohort or serving a given number of students if taxpayers decided to scale it up). Recall that ASAP has a 3-year graduation rate of almost $55 \%$, in contrast to about $24 \%$ for the traditional program. If, for example (among students who meet ASAP's eligibility requirements in 2007 at time of enrollment), 1,000 students entered the traditional program, about 241 would be expected to graduate in 3 years. However, if 1,000 students entered the ASAP program, we would expect more than twice as many, about 549, to graduate. Using the cost and net benefit per graduate and the number of graduates in each group (and assuming no changes in the differential attrition of students in the treatment and comparison groups, economies of scale, and/or general equilibrium effects would operate in changing the scale of ASAP), the total fiscal return on investment showed much larger returns to the public investment in ASAP than in the traditional program. As shown in Table 9 for this simulation, the total net benefits associated with the enrollment of 1,000 students in ASAP would be about $\$ 46$ million higher than the net benefits associated with a similar initial enrollment for the comparison group. This is a sizable advantage in the impact of tax resources in favor of ASAP, as well as in inducing considerably higher efficiency in assisting community college students to complete their studies-a winning strategy for students, taxpayers, and CUNY.

Table 9. Net present value of the taxpayer investment for 1,000 ASAP enrollees versus 1,000 traditional students.

\begin{tabular}{lcccc}
\hline & Enrollees & $\begin{array}{c}\text { Graduates Per 1,000 } \\
\text { Enrollees }\end{array}$ & $\begin{array}{c}\text { Net Benefits Per } \\
\text { Graduate }\end{array}$ & $\begin{array}{c}\text { Total Net Benefits Per 1,000 } \\
\text { Enrollees }\end{array}$ \\
\hline Comparison Group & 1,000 & 241.2 & $\$ 139,600$ & $\$ 33,672,000$ \\
ASAP Cohort & 1,000 & 548.6 & $\$ 146,200$ & $\$ 80,205,000$ \\
Difference (ASAP- & & & $\$ 6,600$ & $\$ 46,533,000$ \\
$\quad$ Comparison) & & & & \\
\hline
\end{tabular}

Note. ASAP = Accelerated Study in Associate Programs. In constant 2010 dollars. Monetary values have been rounded to the closest hundred-dollar value. Totals may not sum to total due to rounding. 
Table 10. Net benefits for the student: Total student costs versus benefits.

\begin{tabular}{lcccc}
\hline & $\begin{array}{c}\text { After-Tax Income Benefits } \\
\text { per Degree (Student) }\end{array}$ & $\begin{array}{c}\text { Total Cost Per } \\
\text { Degree (Student) }\end{array}$ & $\begin{array}{c}\text { Benefits Minus Costs } \\
\text { (Net Benefits) } \\
\text { (Student) }\end{array}$ & $\begin{array}{c}\text { Benefit- } \\
\text { Cost } \\
\text { Ratio } \\
\text { (Student) }\end{array}$ \\
\hline $\begin{array}{l}\text { Fall 2006 Comparison } \\
\text { Group }\end{array}$ & $\$ 158,700$ & $\$ 21,000$ & $\$ 137,700$ & 7.6 \\
Fall 2007 ASAP Group & $\$ 158,700$ & $\$ 13,100$ & $\$ 145,700$ & 12.1 \\
\hline
\end{tabular}

Note. ASAP = Accelerated Study in Associate Programs. In constant 2010 dollars. Monetary values have been rounded to the closest hundred-dollar value. Totals and ratios may not sum to total due to rounding.

\section{Net benefits of ASAP for students}

As explained, we have limited the benefit-cost analysis for additional graduates to the analysis of their higher incomes. Although the graduates also benefit from improvements in their health, lower probability of criminal involvement, and less dependence on public assistance, we did not have accurate estimates of the value of these benefits for the students. The total direct benefit of the associate graduate in additional income beyond that of a high school graduate is shown in Table 10. These incremental income gains were calculated after the student payed income taxes on gross earnings differences. The income gains minus costs paid by the student were about $\$ 138,000$ for each additional graduate in the comparison group and about $\$ 146,000$ for each additional graduate in ASAP. The benefit-to-cost ratio for the associate degree recipient was 7.6 for each additional graduate in the comparison group and 12.1 for each additional ASAP graduate. Another way of stating the gains to the student beyond the costs paid (including forgone earnings for 3 years) is that the income advantage of an associate degree beyond high school completion is the equivalent of being given a CD of about $\$ 140,000$ net of taxes, a powerful incentive for students to undertake an associate degree at CUNY.

\section{Sensitivity analysis}

All estimates of benefits and costs require assumptions and data on which the calculations are based. As the cost-related analyses' methodologies advise, it is important to challenge key assumptions to ascertain their validity and to estimate consequences for the results if other plausible assumptions were used (Levin \& Belfield, 2015). Three potential sources of concern that can affect the estimates are insufficient recognition of comprehensiveness of benefits, external effects of the investment, and mobility of graduates. ${ }^{31}$

\section{Comprehensiveness of benefits}

As McMahon (2009) elaborated, there are many benefits of educational investments for both the individual and for society. Because many of these 
benefits cannot be readily measured or lack good data, we have not included them in this study. For students, we included only the higher incomes represented by their greater employment and higher productivity. We did not include the value of the benefits to the educated person of better adult health, greater life expectancy, improved educational development and health status of offspring, or better consumer decisions, all of which have been linked by McMahon (2009) and others (e.g., Haveman \& Wolfe, 1984) to education. This is also true for such social benefits emanating from a more educated population such as a better-functioning democracy, scientific and cultural progress, and greater equity and social opportunities for those from lower-income backgrounds (Blomquist, Coomes, Jepsen, Koford, \& Troske, 2014). Our lack of ability to measure and obtain data on a full range of benefits means that the full benefits are even greater, perhaps much greater, than those we have captured. Thus, our estimates of net benefits are highly conservative. $^{32}$

\section{Externalities}

Benefits to New York City and its taxpayers are not limited just to those who have received the associate degree. The economics literature has demonstrated that as the educational level of a city rises, there are also benefits to workers with other levels of education. These externalities or spillover benefits result because a higher average level of education in the labor force also improves the productivity of other workers, even those with lower levels of education. The production of goods and services becomes more efficient with benefits that extend beyond just those who have been able to increase their own education.

For example, manufacturing plants located in cities where the fraction of college graduates grew faster experienced larger increases in productivity than similar plants in cities where the fraction of college graduates grew more slowly (Moretti, 2004b, p. 683). A 1-percentage-point increase in college graduates was associated with a $0.5 \%$ to $0.7 \%$ increase in productivity and a $1.1 \%$ increase in wages (Moretti, 2004b, pp. 683-684 and footnote 45). Research has also shown that as the share of college-educated persons rises in a city, the wages of groups with other levels of education also benefit (Abel \& Deitz, 2012; Moretti, 2004a). McMahon (2006) estimated that the contribution of the aggregate education of the labor force to the earnings of workers of any given level of education was substantial.

\section{Mobility}

A further concern for sensitivity analysis is the issue of whether the benefits of taxpayer investment remain in the city and state whose taxpayers have made the investment. If many individuals move to other jurisdictions, the 
benefits will go to taxpayers in those places rather than New York City or New York state. To assess the return on the city's and state's investment in promoting the graduation of CUNY's associate degree students, we examined the mobility of the graduates from CUNY. We used the information from the Office of Policy Research (2011), which surveyed a random sample of CUNY graduates (holding AA, BA, MA, JD, and $\mathrm{PhD}$ degrees) who graduated from 1981 to 2008, to learn the proportion of associate degree graduates currently residing in New York City or New York State. ${ }^{33}$ Among associate degree graduates, the proportions residing in the city or state were as high as $97 \%$ for recent graduates and 89\% even for those graduating as long ago as 1981 . Thus, we can conclude that an overwhelming proportion of the total benefits estimated is provided to New York City taxpayers.

New York state taxpayers also get a substantial share of benefits from the presence of both New York City resident graduates and those in other parts of the state. Even if we assume that only $80 \%$ of the associate degree graduates stay in New York City after completing their degrees, the taxpayer benefits would still be several times the taxpayer costs.

\section{Conclusions: a highly productive investment}

This article has undertaken an economic analysis of both public investment by the taxpayer and private investment of the student to compare the benefits and costs for each constituency of investing in ASAP. An earlier study established that although ASAP underwrites the cost of additional services relative to those allotted to the conventional associate degree program, the greater success of ASAP enrollees in completing the associate degree within 3 years more than compensates for the extra costs (Levin \& Garcia, 2012). In fact, the cost for each ASAP degree is less than that of the conventional program because of its higher success rate of completion.

But beyond the cost per graduate, we asked if there was a positive financial return on the ASAP investment for the taxpayer and for the students in the program. Two types of analysis were undertaken, one from the perspective of the taxpayer and one from the perspective of the student. The benefits to the taxpayer were compared to the taxpayer cost per 3-year associate degree under ASAP and the traditional program. The returns to the taxpayer were composed of the additional tax revenues from the higher income of associate degree graduates as well as the reduced cost of public services associated with the associate degree recipients relative to high school completers. To make comparisons over a lifetime for the gains in tax revenues and reduction of public costs, this analysis drew on official data sources for New York City and New York state. Lifetime benefits were converted to their PV at age 23 years and were compared to the taxpayer and student investment cost valued at age 23 years. In both cases, the benefits far exceeded costs. For each dollar of investment in ASAP by taxpayers, the return 
was $\$ 3$ to $\$ 4$. For each dollar of investment by students, the return was much more, even when including forgone earnings by students as the major component of student costs. Using available data on which public constituencies receive the benefits-federal, New York state, and New York City governments-we believe that all constituencies receive benefits that exceed their cost contributions to the investment (see Levin \& Garcia, 2013, Table A5).

From a policy perspective, it is important to keep in mind the full magnitude of the returns to the taxpayer by taking into account the highly superior effectiveness of ASAP in comparison with the conventional program (completion rates of about 55\% for ASAP versus 24\% for the conventional program, for students meeting ASAP's eligibility requirements when the program was launched in 2007). For every 1,000 enrollees in ASAP, about 549 would be expected to complete the associate degree requirement in 3 years, compared with only about 241 in the conventional program. When converted into overall benefits generated by the 1,000 enrollees, the considerably higher productivity of ASAP in producing associate degrees would provide fiscal benefits to taxpayers of $\$ 46$ million beyond those of investing an approximately equal amount in the conventional degree program.

This evaluation of ASAP might be used as a guide for a comprehensive evaluation of the economic impact of cost-effectiveness and investment returns on social investments in higher education. ASAP is less costly per additional graduate and twice as effective in the production of associate degrees. From the perspective of both the taxpayer and student, ASAP provides healthy investment returns. We believe that these results provide traction for convincing taxpayers and their representatives to invest in such programs. In the present case, the analysis of costs and returns induced funding commitments for scale-up of ASAP from its initial trial of about 1,000 students in $2007-2010$ to 15,000 by $2016-2017$, with a future commitment to 25,000 by $2018-2019$.

\section{Notes}

1. City University of New York Office of Institutional Research and Assessment's analysis of data from the Integrated Postsecondary Education Data System revealed that nationally, only $16 \%$ of urban community college students graduate within 3 years (CUNY Office of Institutional Research and Assessment, 2012).

2. When ASAP began in 2007, the 3-year CUNY community college graduation rate was $24 \%$ for skill-proficient students, based on a CUNY analysis of student-level data from the CUNY Institutional Research Database, and 13\% for all first-time full-time community college students who entered in fall 2004 regardless of skills proficiency (CUNY Office of Institutional Research and Assessment, 2012).

3. Borough of Manhattan, Bronx, Hostos, Kingsborough, La Guardia, and Queensborough Community Colleges. 
4. The second ASAP cohort admitted in 2009 also realized a 3-year graduation rate of $55 \%$ versus $23 \%$ for a comparison group of similar students (Linderman \& Kolenovic, 2013).

5. The evaluation was conducted by Metis Associates. The results of the optimal matching for CUNY ASAP conducted by Jing Zhu are available in Linderman and Kolenovic (2012, Appendix C). Other covariates used in the propensity score-matching analyses are applying for financial aid (Pell and Tuition Assistance Program [TAP]), cumulative grade point average, and cumulative credit.

6. Updated analyse for recent years and cohorts, some using random assignment (which ensures unbiased impact estimates with external validity limitations), have been provided by Scrivener, Weiss, and Sommo (2012), Scrivener and Weiss (2013), Kolenovic, Linderman, and Karp (2013), and Scrivener et al. (2015). The latter evaluation estimated that for students with development education needs in 3 colleges, $40 \%$ of the ASAP program group received a degree within 3 years compared with $22 \%$ of the control group, using random assignment to ASAP and a control group.

7. For arguments explaining the importance of cost-benefit and cost-effectiveness analyses for policy and decision making, see Levin and McEwan (2001), Evans and Ghosh (2008), and García (2015).

8. In other words, the counterfactual used in the evaluations of the program's impacts by CUNY and MDRC is the increased number of graduates among ASAP participants versus the traditional program or comparison group. The benefits and costs of an additional degree under ASAP and following the traditional program are estimated by comparing the net benefits, after costs are accounted for, of graduating versus not graduating (i.e., receiving a high school diploma) in both cases.

9. Following the cost-benefit analyses described herein, the benefits of a higher educational attainment (associate degree $[\mathrm{AA}]$ completion) are measured relative to the benefits of high school completion. Because CUNY was producing graduates from both ASAP and in the traditional program, we calculated the incremental benefits and costs (relative to those of high school completion) for associate degree completion of the two alternatives. The benefits of completing an associate degree were similar for the two alternatives-as graduation requirements are the same and students are comparable at the baseline on observable characteristics, as determined by propensity score matching. However, the cost per graduate to the taxpayer differs depending on whether the graduate came from the treatment or the comparison group. In our analysis, we compared the benefits and costs of completing an associate degree relative to high school completion under both ASAP and the traditional program. It should be noted that experimental estimates for later cohorts in randomized controlled trials have yielded comparable results of the program's impact to the ones used in this study, with graduation rates in the treatment group doubling those in the control group, even under different student eligibility requirements (Scrivener et al., 2015).

10. All comparisons of benefits and costs were based on differences between high school graduates and associate degree graduates. We attempted to include analyses for partial completers but were not able to obtain the necessary data. The omission of benefits to partial completers imparts a downward bias to benefits.

11. The average age of a 3-year graduate was 23 years for ASAP, based on a mean starting age of 20 years (see Linderman \& Kolenovic, 2012, p. 17).

12. The debate on discount rates is generally resolved in this range for social investments, but it is still under debate in the literature (Benzoni \& Chyruk, 2015; Moore, Boardman, \& Vining, 2013). 
13. Both independent studies and government studies by the Department of Justice or the Department of Health and Human Services have provided systematic information for the nation and states that link education to crime and to health, respectively. But systematic studies at local levels are rare to nonexistent. The relation between education and income and its yield of government tax revenues are available from the U.S. Department of Commerce, and, particularly, the Bureau of the Census, as well as state and local agencies. A summary of sources of information utilized throughout the analysis, by category of benefits, is available upon request.

14. The estimates of the net benefits to the student are also conservative, as they are limited by data availability to the higher personal income generated by the investment and omitting personal benefits from improvements in their health (see McMahon, 2009, for an estimate of individual health benefits), lower probability of criminal involvement, and less dependence on public assistance.

15. Blomquist et al. (2014) is a recent example of an evaluation estimating the social value of higher education.

16. FTE students is a commonly used measure for enrollments that adjusts the number of students by the number of credits of study they have undertaken.

17. These institutional costs did include some student costs in terms of tuition and fees for non-ASAP students. However, in the analysis, we assumed that all the institutional costs were paid by the taxpayer, which further contributes to providing a conservative estimate for the net benefits (minus costs) to the taxpayer. These portions of costs could be partially double-counted in this study, but their nominal magnitude has no major consequences for the results and conclusions. See a detailed table and explanations in Levin and Garcia (2013).

18. http://www.cuny.edu/admissions/tuition-fees.html

19. Forgone earnings were calculated as the difference between the average earnings of a full-time worker with a high school degree and the average earnings of an enrollee in a public institution (aged 20-22 years), both expressed as PV at age 23 years and in 2010 dollars.

20. http://www.cuny.edu/admissions/tuition-fees.html

21. Educational attainment in the ACS and Census data was defined as (a) high school graduate or GED, regular high school diploma, GED or alternative credential, and (b) associate degree, type not specified.

22. We refer to earnings and income interchangeably. They are not identical. Earnings are derived from wages and salaries; income includes not only wages and salary, but also rents, dividends, and interest from property, etc. However, for high school and associate degree populations, the proportion of income from earnings is usually $95 \%$ or greater.

23. See Levin and Garcia (2013) for information on associations between education and categories of benefits examined in the article, as well as for breakdowns by gender or race in some cases.

24. Detailed descriptive information of the ACS data by year is available upon request. Linderman and Kolenovic (2012) provided the descriptive information for the students in the first ASAP cohort and in the comparison group (see Table 1). In terms of race breakdown, the ACS demographics are in between the demographics for the treatment group and the control group. In terms of gender, about 54\% of students in ASAP (and $53 \%$ in the comparison group) were women, relative to $50 \%$ in ACS. Mean household income in ACS was higher than mean household income for CUNY students. As explained in Levin and Garcia (2013), estimates of the PV of earnings by gender and race showed that the difference between earnings (and hence taxes) for an associate 
degree over high school completion for each gender and race group was relatively similar (it varied from about $\$ 310,000$ to about $\$ 362,000$ ). Therefore, any difference in the demographic composition of CUNY students relative to the Census data would not be expected to seriously distort the results, on average.

25. Tax contributions were calculated based on earnings, as a proxy for an individual's total income. For the groups studied in the report, earnings constituted more than $90 \%$ of income.

26. Available at http://users.nber.org/ taxsim/taxsim-calc9.

27. The NBER's tax simulator allows for specifying only the state but not the exact city where the individual lives. In contrast, the calculations corresponding to other taxes calculated in the section "Additional Tax Revenues from City Income, Property, and Sales Taxes" (city income, property and sales taxes) were estimated using information pertaining to individuals who reside in New York City.

28. Rouse (2007) and Levin et al. (2007) also estimated tax contributions for single individuals. See tax contributions from earnings for married people in Levin and Garcia (2013), Appendix B. Total taxes for married people were, on average, 15\% lower than for single people.

29. MEPS reports years of education of the individuals at the time the individual joined the study rather than degree received (i.e., if an individual earned any educational credential afterward, his educational attainment would be underreported). We assumed 12 years of education is equivalent to a high school degree and 14 years of education is equivalent to an associate degree. We limited our analysis to data for individuals residing in the Northeast region, within a metropolitan statistical area.

30. According to the definition of variables in Integrated Public Use Microdata Series census microdata for social and economic research), this variable reports how much pretax income (if any) the respondent received during the previous year from various public assistance programs commonly referred to as "welfare." Assistance from private charities was not included, but the following were included: federal/state Supplemental Security Income payments to elderly (age 65 years and older), blind, or disabled persons with low incomes; Aid to Families with Dependent Children; and General Assistance.

31. For selection of discount rate chosen, please see "Methods" section.

32. Another excluded benefit is the higher likelihood of students in ASAP enrolling in 4-year institutions and pursuing more education. Based on Linderman and Kolenovic (2012), CUNY-ASAP estimates that transfer rates to a 4-year institution of ASAP students who received the associate degree are higher than those of associate degree recipients in the comparison group. Specifically, $72.4 \%$ of ASAP associate degree recipients versus $62.2 \%$ of associate degree recipients in the comparison group transferred to a baccalaureate institution. Strumbos and Kolenovic (2016) estimated the effects of ASAP on enrollment in a baccalaureate program, associate degree attainment, bachelor's degree attainment, any degree attainment, and time to degree using information from the first three cohorts (6year outcomes). They estimated effects of $9,21,7$, and 18 percentage points on the four first outcomes, respectively, and a -1.51 semester reduction in the time-to-degree outcome (propensity score-matching results). Eight-year outcomes for ASAP's first cohort of students (fall 2007 cohort, the only cohort so far with 8 years of data) showed that $33.5 \%$ had earned a bachelor's degree (a gain of 8 percentage points relative to the comparison group). With a longer timeframe that makes data available, future work by CUNY is expected to provide information on differences in labor market outcomes for the two groups.

33. The survey examined the cohorts graduating every 3 years, a sample composed of nearly 13,000 graduates. See Levin and Garcia (2013), Figure 4. 


\section{Acknowledgments}

The authors wish to extend thanks to Donna Linderman, Colin Chellman, Zineta Kolenovic, Simon McDonnell, Brooks Bowden, and two anonymous reviewers who provided valuable comments.

\section{Funding}

Special thanks to the New York City Center for Economic Opportunity for support of this study.

\section{ORCID}

Emma García 은 http://orcid.org/0000-0001-7255-1651

\section{References}

Abel, J. R., \& Deitz, R. (2012). Do colleges and universities increase their region's human capital? Journal of Economic Geography, 12, 667-691. doi:10.1093/jeg/lbr020

Angrist, J. D., \& Krueger, A. B. (1991). Does compulsory school attendance affect schooling and earnings? Quarterly Journal of Economics, 106, 979-1014. doi:10.2307/2937954

Angrist, J. D., \& Krueger, A. B. (1999). Empirical strategies in labor economics. Handbook of Labor Economics, 3(Part A), 1277-1366.

Ashenfelter, O., \& Rouse, C. (1998). Income, schooling, and ability: Evidence from a new sample of identical twins. Quarterly Journal of Economics, 113, 253-284. doi:10.1162/ 003355398555577

Barnett, W. S. (1985). Benefit-cost analysis of the Perry Preschool Program and its policy implications. Educational Evaluation and Policy Analysis, 7, 333-342. doi:10.3102/ 01623737007004333

Becker, G. S. (1964). Human capital: A theoretical and empirical analysis with special reference to education (3rd ed.). New York, NY: National Bureau of Economic Research.

Becker, G. S., \& Mulligan, C. B. (1997). The endogenous determination of time preference. Quarterly Journal of Economics, 112, 729-758. doi:10.1162/003355397555334

Belfield, C. R., \& Levin, H. M. (2007a). The economic losses from high school dropouts in California. Santa Barbara: California Dropout Recovery Project, University of California, Santa Barbara. Retrieved from http://cdrpsb.org/download.php?file=researchreport1.pdf

Belfield, C. R., \& Levin, H. M. (2007b). The price we pay: The economic and social costs of inadequate education. Washington, DC: Brookings Institution Press.

Belfield, C. R., Levin, H. M., \& Rosen, R. (2012). The economic value of opportunity youth. Civic Enterprises. Retrieved from http://www.civicenterprises.net/MediaLibrary/Docs/ econ_value_opportunity_youth.pdf

Belfield, C. R., Nores, M., Barnett, W. S., \& Schweinhart, L. (2005). Updating the economic impacts of the High/Scope Perry Preschool Program. Educational Evaluation and Policy Analysis, 27, 245-261. doi:10.3102/01623737027003245

Benzoni, L., \& Chyruk, O. (2015). The value and risk of human capital (Working Paper No. 2015-06). Chicago, IL: Federal Reserve Board of Chicago.

Blomquist, G. C., Coomes, P. A., Jepsen, C., Koford, B. C., \& Troske, K. R. (2014). Estimating the social value of higher education: Willingness to pay for community and technical colleges. Journal of Benefit-Cost Analysis, 5, 3-41. doi:10.1515/jbca-2013-0009 
Bureau of the Census, U.S. Department of Commerce. (2012). Statistical Abstract of the United States: 2012 (131st Edition). The national data book. Washington, DC: U.S Government Printing Office, Table 278. Retrieved from ftp://ftp.census.gov/library/publica tions/2011/compendia/statab/131ed/tables/12s0278.pdf; https://www.census.gov/prod/ 2011pubs/12statab/educ.pdf

Card, D. (1999). The causal effect of education on earnings. Handbook of Labor Economics, 3 (Part A), 1801-1863.

Chernick, H., \& Reimers, C. (2004). The decline in welfare receipt in New York City: Push or pull? Eastern Economic Journal, 30, 3-29.

City University of New York Office of Institutional Research. (2012). System retention and graduation rates of full-time first-time freshmen in associate programs by year of entry: Community colleges. Retrieved from http://www.cuny.edu/irdatabook/rpts2_AY_current/ RTGS_0015_FT_FTFR_ASSOC_CC_TOT_UNIV.rpt.pdf

City University of New York, Office of Policy Research. (2011). Do CUNY graduates stay in New York? Retrieved from http://cuny.edu/about/administration/offices/ira/opr/briefs/NY_ Residency_Research_brief_v_11_rev20121022.pdf

Cutler, D. M., \& Lleras-Muney, A. (2010). Understanding differences in health behaviors by education. Journal of Health Economics, 29, 1-28. doi:10.1016/j.jhealeco.2009.10.003

Evans, D., \& Ghosh, A. (2008). Prioritizing educational investments in children in the developing world (RAND Working Paper, No. WR-587). Santa Monica, CA: Rand Corporation. Retrieved from http://www.rand.org/pubs/working_papers/WR587.html

García, E. (2015). Evaluación de las Políticas Públicas para el Desarrollo: Efectividad, Eficiencia y Rentabilidad [Evaluation of Public Policy: effectiveness, efficiency and returns to the investment]. Revista de Información Económica, Ministerio de Economía $y$ Competitividad, 880, 151-161. Retrieved from https://www.researchgate.net/publication/ 280741972_Evaluacion_de_las_Politicas_Publicas_para_el_Desarrollo_Efectividad_ Eficiencia_y_Rentabilidad

Griliches, Z. (1979). Sibling models and data in economics: Beginnings of a survey. Journal of Political Economy, 87(5, Part 2), S37-S64. doi:10.1086/260822

Haveman, R., \& Wolfe, B. (1984). Schooling and economic well-being: The role of nonmarket effects. Journal of Human Resources, 19, 377-407. doi:10.2307/145879

Kolenovic, Z., Linderman, D., \& Karp, M. M. (2013). Improving student outcomes via comprehensive supports: Three-year outcomes from CUNY's Accelerated Study in Associate Programs (ASAP). Community College Review, 41, 271-291. doi:10.1177/ 0091552113503709

Levin, H. M. (1972). The costs to the nation of inadequate education (Report to the Select Committee on Equal Educational Opportunity, U.S. Senate, 92d Cong.). Washington, DC: U.S. Government Printing Office.

Levin, H. M., \& Belfield, C. (2015). Guiding the development and use of cost-effectiveness analysis in education. Journal of Research on Educational Effectiveness, 8(3), 400-418. doi:10.1080/19345747.2014.915604

Levin, H. M., \& Belfield, C. R. (2007). Educational interventions to raise high school graduation rates. In C. R. Belfield \& H. M. Levin (Eds.), The price we pay: Economic and social consequences for inadequate education (pp. 177-199). Washington, DC: Brookings Institution.

Levin, H. M., Belfield, C., Muennig, P., \& Rouse, C. (2007). The costs and benefits of an excellent education for all of America's children. New York, NY: Center for Benefit-Cost Studies in Education, Teachers College, Columbia University.

Levin, H. M., \& Garcia, E., with the assistance of Morgan, J. (2012). Cost-effectiveness of the Accelerated Study in Associate Programs (ASAP) of the City University of New York. New 
York, NY: Center for Benefit-Cost Studies in Education, Teachers College, Columbia University.

Levin, H. M., \& Garcia, E. (2013). Benefit-cost analysis of the Accelerated Study in Associate Programs (ASAP) of the City University of New York (CUNY). New York, NY: Center for Benefit-Cost Studies in Education, Teachers College, Columbia University.

Levin, H. M., \& McEwan, P. (2001). Cost-effectiveness analysis: Methods and applications. Thousand Oaks, CA: Sage.

Linderman, D. \& Kolenovic, Z. (2013). Moving the completion needle at community colleges: CUNY's accelerated study in associate programs (ASAP). Change: The Magazine of Higher Learning, 45(5), 43-50. doi:10.1080/00091383.2013.824350

Linderman, D., \& Kolenovic, Z. (2012). Results thus far and the road ahead: A follow-up report on CUNY Accelerated Study in Associate Programs (ASAP). New York: City University of New York. Retrieved from http://www1.cuny.edu/sites/asap/wp-content/ uploads/sites/8/2014/06/ASAP_Followup_Report_PDF.pdf

Lleras-Muney, A. (2005). The relationship between education and adult mortality in the United States. Review of Economic Studies, 72, 189-221. doi:10.1111/j.1467937X.2006.00398.x

Lochner, L. (2011). Non-production benefits of education: Crime, health, and good citizenship (NBER Working Paper No. 16722). Cambridge, MA: National Bureau of Economic Research.

Lochner, L., \& Moretti, E. (2004). The effect of education on crime: Evidence from prison inmates, arrests, and self-reports. American Economic Review, 94, 155-189. doi:10.1257/ 000282804322970751

Marcotte, D., Bailey, T., Borkoski, C., \& Kienzl, G. (2005). The returns of a community college education: Evidence from the National Education Longitudinal Survey. Educational Evaluation and Policy Analysis, 27, 157-175. doi:10.3102/01623737027002157

McMahon, W. W. (2006). Education finance policy: Financing the non-market and social benefits. Journal of Education Finance, 32, 264-284.

McMahon, W. (2009). Higher learning and the greater good: The private and social benefits of higher education. Baltimore, MD: Johns Hopkins University Press.

Moore, M. A., Boardman, A. E., \& Vining, A. R. (2013). More appropriate discounting: The rate of social time preference and the value of the social discount rate. Journal of BenefitCost Analysis, 4, 1-16. doi:10.1515/jbca-2012-0008

Moore, M. A., Boardman, A. E., Vining, A. R., Weimer, D. L., \& Greenberg, D. H. (2004). 'Just give me a number!' Practical values for the social discount rate. Journal of Policy Analysis and Management, 23, 789-812. doi:10.1002/pam.20047

Moretti, E. (2004a). Estimating the social return to higher education: Evidence from longitudinal and repeated cross-sectional data. Journal of Econometrics, 121, 175-212. doi:10.1016/j.jeconom.2003.10.015

Moretti, E. (2004b). Workers' education, spillovers, and productivity: Evidence from plantlevel production functions. American Economic Review, 94, 656-690. doi:10.1257/ 0002828041464623

Moretti, E. (2007). Crime and the costs of criminal justice. In C. R. Belfield \& H. M. Levin (Eds.), The price we pay: Economic and social consequences for inadequate education (pp. 142-160). Washington, DC: Brookings Institution.

Muennig, P. (2007). Consequences in health status and costs. In C. R. Belfield \& H. M. Levin (Eds.), The price we pay: Economic and social consequences for inadequate education (pp. 125-141). Washington, DC: Brookings Institution. 
Rouse, C. (2007). Consequences for the labor market. In C. R. Belfield \& H. M. Levin (Eds.), The price we pay: Economic and social consequences for inadequate education (pp. 99-124). Washington, DC: Brookings Institution.

Scrivener, S., \& Weiss, M. J. (2013). More graduates. New York, NY: MDRC.

Scrivener, S., Weiss, M. J., Ratledge, A., Rudd, T., Sommo, C., \& Fresques, A. (2015). Doubling graduation rates: Three-year effects of CUNY's Accelerated Study in Associate Programs (ASAP) for developmental education students. New York, NY: MDRC.

Scrivener, S., Weiss, M. J., \& Sommo, C. (2012). What can a multifaceted program do for community college students? Early results from an evaluation of Accelerated Study in Associate Programs (ASAP) for developmental education students. New York, NY: MDRC.

Snider, T. A., \& Dillow, S. A. (2011). Digest of education statistics, 2010, NCES 2011015, Table 341. Washington, DC: National Center for Education Statistics, U.S. Department of Education. Retrieved from http://nces.ed.gov/programs/digest/d10/tables/dt10_341.asp

Strumbos, D., \& Kolenovic, Z. (2016, November). The longer term picture: Six-year outcomes of CUNY Accelerated Study in Associate Programs (ASAP). Paper presented at the Association for Public Policy Analysis and Management Fall Research Conference, Washington, DC.

Trostel, P. (2010). The fiscal impacts of college attainment. Research in Higher Education, 51, 220-247. doi:10.1007/s11162-009-9156-5

Waldfogel, J., Garfinkel, I., \& Kelly, B. (2007). Welfare and the costs of public assistance. In C. R. Belfield \& H. M. Levin (Eds.), The price we pay: Economic and social consequences for inadequate education (pp. 162-174). Washington, DC: Brookings Institution.

The White House. (2014a). FACT SHEET: Improving college opportunity. Retrieved from https://www.whitehouse.gov/the-press-office/2014/08/13/fact-sheet-improving-collegeopportunity

The White House. (2014b). Increasing college opportunity for low-income students. Promising models and a call to action. Washington, DC: Executive Office of the President. 